\title{
Pengaruh Aspek Sumber Daya Manusia Terhadap Jumlah Kriminalitas di Sumatera Selatan Tahun 2019
}

\author{
Yunita Febriani \\ Fakultas Ekonomi dan Bisnis Universitas Muhammadiyah Palembang, yunitafebriani.ump@gmail.com
}

\begin{abstract}
ABSTRAK
Jumlah kriminalitas di Sumatera Selatan masih sangat tinggi pada Tahun 2019, dengan selang waktu terjadinya tindak pidana tersingkat yaitu 2 jam, hal ini menjadi suatu permasalahan yang meresahkan masyarakat. Kriminalitas merupakan suatu perbuatan yang bertentangan dengan undang-undang, merugikan korban maupun masyarakat dengan merusak ketentraman dan ketertiban. Salah satu cara mengurangi tindak kriminalitas yaitu dengan memprediksi faktor-faktor apa saja yang mempengaruhinya. Penelitian ini bertujuan untuk menganalisis faktor pengaruh kriminalitas di Sumatera Selatan ditinjau dari aspek Sumber Daya Manusia yaitu jumlah penduduk miskin, tingkat pengangguran terbuka, kepadatan penduduk, nilai IPM dan PDRB. Data dianalisis menggunakan Analisis Regresi Linier. Hasil penelitian menunjukkan bahwa model variabel jumlah penduduk miskin, tingkat pengangguran terbuka, kepadatan penduduk dan PDRB berpengaruh positif terhadap kriminalitas. Sedangkan variabel IPM memberikan pengaruh negatif terhadap kriminalitas. Nilai $\mathrm{R}^{2}$ yang diperoleh sebesar $98,5 \%$, artinya model yang diperoleh sudah sangat baik untuk menggambarkan pengaruh variabel-variabel bebas terhadap jumlah kriminalitas di Sumatera Selatan.
\end{abstract}

Kata Kunci: Analisis Regresi Linier, Kriminalitas, Sumatera Selatan, Sumber Daya Manusia

\begin{abstract}
The number of crime in South Sumatra is still very high in 2019, with the shortest time interval for the occurrence of criminal acts of 2 hours, this is a problem that is troubling the community. Criminality is an act that is against the law, harming the victim and society by destroying peace and order. One way to reduce crime is by predicting the factors that influence it. This study aims to analyze the influence factors of crime in South Sumatra in terms of human resources, there are the number of poor people, the level of open unemployment, population density, the value of IPM and PDRB. Data were analyzed using Linear Regression Analysis. The results showed that the variable model number of poor people, open unemployment rate, population density and PDRB had a positive effect on crime. Meanwhile, the IPM variable has a negative effect on crime. The $R^{2}$ value obtained is $98.5 \%$, meaning that the model obtained is very good at describing the effect of independent variables on the number of crimes in South Sumatra.
\end{abstract}

Keywords : Crime; Human Resource; Linier Regression Analysis; South Sumatera.

\section{A. PENDAHULUAN}

Sumatera Selatan merupakan salah satu provinsi besar di Indonesia, yang terdiri dari 17 kota/kabupaten. Salah satu permasalahan yang masih saja dirasakan yaitu masih maraknya terjadi kasus kriminalitas. Berdasarkan data dari BPS, 2019, angka kejahatan yang ter lapor masih sangat tinggi, yaitu sebanyak 11618 kasus. Sedangkan selang waktu terjadinya tindak pidana tersingkat yaitu selang waktu 2 jam terjadi di Kota Palembang dan terlama yaitu selang waktu 56 jam terjadi di Kota Pagar Alam. Hal ini tentunya sangat meresahkan masyarakat dan masih menjadi pekerjaan yang sangat berat bagi pihak terkait di Provinsi Sumatera Selatan untuk 
menurunkan angka tersebut. Kriminalitas sangat meresahkan, mengganggu dan menimbulkan kecemasan di masyarakat.

Berdasarkan data BPS, jumlah korban kejahatan di Sumatera Selatan didominasi oleh perempuan baik pada kelompok usia dewasa maupun kelompok usia anak-anak (BPS, 2020).

Standar kesuksesan suatu pembangunan negara salah satunya dapat dilihat dari pertumbuhan ekonomi dan Sumber Daya Manusia (SDM) dari negara tersebut. Menurut Seer dalam Mardiyansyah (2020), bahwa pembangunan suatu negara dikategorikan berhasil jika dapat mengatasi masalah kemiskinan, ketimpangan ekonomi dan pengangguran. Jika ketiga hal tersebut belum dapat teratasi maka akan menimbulkan banyak permasalahan, diantaranya banyaknya pengangguran dan tindak kriminalitas.

Menurut Silo 1985 dalam Mardiyansyah dkk, (2020), Kriminalitas merupakan suatu perbuatan yang bertentangan dengan undang-undang, merugikan korban maupun masyarakat dengan merusak ketentraman dan ketertiban. Sedangkan definisi kriminalitas menurut polri adalah perbuatan seseorang yang dapat diancam hukuman berdasarkan KUHP. Tidak kriminalitas tentu saja dipengaruhi oleh berbagai faktor, baik faktor internal dan faktor eksternal dari pelaku tindak kriminal tersebut. Menurut Kartono, 1999, faktor-faktor yang menyebabkan terjadinya tindak kejahatan adalah faktor biologi, sosiologi. Faktor sosiologi tersebut terdiri dari faktor ekonomi, faktor mental, faktor fisik, dan faktor pribadi.

Faktor ekonomi dapat ditinjau dari jumlah pengangguran dan kemiskinan, sedangkan faktor mental, fisik dan pribadi termasuk dalam kategori kualitas sumber daya manusia yang ada. Sumatera Selatan terdiri dari 17 kota/kabupaten terbagi menjadi daerah perkotaan dan pedesaan, namun secara tindak kriminal tidak ada perbedaan dalam hal perkotaan dan pedesaan. Menurut Sharp, et al 1996, bahwa faktor utama penyebab kriminalitas adalah nafsu dan emosi yang tidak terkendali, kemiskinan, rendahnya nilai-nilai sosial masyarakat.

Menurut Theodore Schultz dalam Wirawan 2015, memperbaiki kesejahteraan orang miskin tidak tergantung pada tanah, peralatan atau energi, akan tetapi lebih bergantung kepada ilmu pengetahuan. Selanjutnya dikatakan bahwa aspek kualitatif ekonomi adalah kapital manusia atau modal manusia. Contoh aset yang tidak terlihat yang menjadi bagian dari modal manusia (human capital) yaitu ilmu pengetahuan dalam diri (tacit knowledge), pendidikan (education), dan pengetahuan yang terkait pekerjaan (work-related know-how).

Permasalahan kriminal merupakan permasalahan kompleks yang harus dipecahkan dalam berbagai aspek, baik internal eksternal masyarakat. Perbaikan permasalahan secara eksternal misalnya melalui program-program yang dibuat oleh pemerintah, seperti menyediakan fasilitas pendidikan yang baik, ketersediaan lapangan pekerjaan yang memadai, dan peningkatan sistem keamanan. Sedangkan faktor internal dalam dari suatu individu yaitu dengan memperbaiki kualitas diri baik sosial dan agama.

Pada tulisan ini akan dibahas bagaimana pengaruh faktor-faktor pada aspek sumber daya manusia terhadap jumlah kriminalitas di Provinsi Sumatera Selatan. Faktor-faktor yang diduga berpengaruh terhadap jumlah kriminalitas adalah jumlah penduduk miskin, tingkat pengangguran terbuka, kepadatan penduduk, dan menggunakan data nilai IPM dan PDRB Perbandingan jumlah tingkat kriminalitas di kota/kabupaten di Sumatera Selatan dilihat berdasarkan data tahun 2019. Salah satu cara mencegah terjadinya kejahatan adalah dengan mengetahui gambaran faktor- 
faktor pengaruh jumlah kriminalitas ini tentunya dapat menjadi pedoman dan acuan bagi pihak terkait untuk dapat menekan jumlah kriminalitas.

Data kriminalitas di Sumatera Selatan dianalisis menggunakan Analisis Regresi Berganda, data yang diperoleh hanya dari $15 \mathrm{kota} / \mathrm{kabupaten}$, hal ini dikarenakan dua kota/kabupaten di Sumatera Selatan lainnya merupakan kota/kabupaten yang baru terbentuk, sehingga data pada kota/kabupaten tersebut belum masuk dalam publikasi BPS tahun 2020. Analisis Regresi Berganda merupakan uji statistik yang digunakan untuk membuat sebuah model persamaan yang dapat digunakan sebagai gambaran seberapa besar pengaruh suatu variabel berpengaruh terhadap variabel lainnya. Gambaran yang disajikan merupakan gambaran hubungan linier antara dua atau lebih variabel. Model yang diperoleh dari Analisis Regresi Linier akan dilihat kebaikannya berdasarkan nilai $R^{2}$ dan akan diuji secara parsial dengan uji t dan di uji secara simultan menggunakan uji F (Mattjik dan Sumertajaya, 2008).

\section{B. KAJIAN TEORI}

Lumenta dkk (2012) menyatakan bahwa jumlah kriminalitas dapat dipengaruhi secara langsung oleh jumlah penduduk, jumlah industri, jumlah kemiskinan dan jumlah pengangguran.

Berdasarkan pendekatan ekonomi, Hardianto (2019) menyatakan bahwa variabel pengeluaran pembangunan pemerintah berpengaruh positif dan signifikan terhadap tindak kriminalitas. Selanjutnya, saran yang diberikan sebagai upaya untuk mengurangi tindak kriminalitas yaitu dengan meningkatkan tingkat upah minimum regional dan mengurangi ketidak-efisienan dan ketidak-efektifan penggunaan dana pengeluaran pembangunan.

Dalam tinjauan literatur terkait faktor sosial ekonomi terhadap perilaku kriminalitas yang dilakukan oleh Andri ddk (2019), dipaparkan bahwa upaya untuk menyeragamkan kondisi sosial ekonomi setiap individu menjadi suatu kemustahilan, oleh karena ini negara telah merespon fenomena kriminalitas dengan upaya menambah petugas polisi, jaksa dan sel penjara unruk memberikan hukuman kepada pelaku kriminalitas. Selain itu telah dilakukan upaya untuk mereduksi kriminalitas dengan menambah jumlah guru dan meningkatkan sumber daya pendidikan. Hal ini dimaksudkan agar kesadaran terhadap hukum masyarakat makin tercipta.

Menurut Alam dan Ilyas dalam Dulkiah dan Nurjanah (2018), terdapat tiga bagian pokok sebagai upaya penanggulangan tindak kriminalitas, yakni Pre-Emtif : upaya pencegahan yakni dengan penanaman nilai dan norma yang baik kepada tiap individu, Preventif : menghilangkan kesempatan untuk dilakukannya tindakan kriminal, dan Represif : upaya yang dilakukan setelah terjadinya tindak kriminal, yaitu dengan memberikan sanksi hukuman kepada pelaku. Selanjutnya Dulkiah dan Nurjanah (2018) menyatakan bahwa terdapat pengaruh yang signifikan antara kemiskinan terhadap tingkat kriminalitas.

Faktor penyebab tindak kriminalitas sangatlah kompleks, baik ditinjau dari aspek sosial ekonomi, individu dan kesempatan. Audey dan Ariusni (2014) mengungkapkan bahwa kriminalitas dipengaruhi signifikan negatif oleh Indeks Pembangunan Manusia (IPM) dan kepadatan penduduk.

Terdapat dua indikator perkembangan manusia yang dijadikan sebagai gambaran kemampuan Sumber Daya Manusia (SDM) bersaing atau tidaknya, yaitu Indeks Perkembangan Manusia dan Angka Kemiskinan. Indeks Perkembangan Manusia adalah suatu ukuran untuk menilai perkembangan jangka panjang SDM 
dengan menggunakan tiga dimensi perkembangan manusia. Tiga indeks perkembangan manusia tersebut yaitu (1) kehidupan panjang dan sehat yang diukur melalui usia harapan hidup (life expectancy) yaitu rat-rata umur manusia. (2) Akses kepada ilmu pengetahuan yang diukur menggunakan jumlah tahun bersekolah untuk populasi orang dewasa, yaitu jumlah rata-rata tahun pendidikan yang diterima sepanjang hidupnya oleh orang berumur 25 tahun lebih. Selanjutnya akses kepada ilmu pengetahuan diukur dengan tahun yang diharapkan untuk bersekolah bagi anak-anak umur masuk sekolah yang merupakan jumlah total tahun sekolah seorang anak umur masuk sekolah yang diharapkan dapat diterima. (3) Standar kehidupan yang layak, diukur dengan Gross Nation Income (GNI) per kapita yang diekspresikan menggunakan kekuatan tingkat pariti daya beli. Pariti daya beli adalah ukuran kekuatan daya beli relatif uang suatu negara terhadap barang dan jasa yang sama di samping tingkat inflasi yang berbeda (Wirawan, 2015)

Kepadatan Penduduk adalah rasio banyaknya penduduk per kilometer persegi. Berdasarkan konsep basic needs approach, BPS mendefinisikan bahwa kemiskinan merupakan kondisi ketidakmampuan dari sisi ekonomi untuk memenuhi kebutuhan dasar makanan dan bukan makanan yang diukur dari sisi pengeluaran. Sedangkan definisi Penduduk Miskin adalah penduduk yang memiliki rata-rata pengeluaran per kapita per bulan di bawah Garis Kemiskinan. Selain itu faktor pengangguran juga berpengaruh terhadap tingkat kriminalitas.

Pengangguran tercipta akibat pertambahan pekerjaan yang lebih rendah dari pertumbuhan jumlah tenaga kerja. Menurut Nadilla dan Talbani (2014), bahwa variabel jumlah pengangguran, pendidikan dan jumlah polisi berpengaruh positif terhadap kriminalitas di Provinsi Aceh.

Menurut Santoso dan Zulfa 2016 cara memberantas kejahatan adalah dengan memperbaiki tingkat kehidupan manusia.

\section{METODE PENELITIAN}

Data merupakan data sekunder yang diperoleh dari publikasi BPS Provinsi Sumatera Selatan yakni pada publikasi Sumatera Selatan Dalam Angka Tahun 2019. Adapun yang menjadi variabel dependen yaitu Jumlah Kriminalitas di 15 kota/kabupaten di Provinsi Sumatera Selatan Tahun 2019. Sedangkan variabel independen nya yaitu Jumlah Penduduk Miskin $\left(X_{1}\right)$, Tingkat Pengangguran Terbuka $\left(\mathrm{X}_{2}\right)$, Kepadatan Penduduk $\left(\mathrm{X}_{3}\right)$, Indeks Pembangunan Manusia $\left(\mathrm{X}_{4}\right)$, dan PDRB $\left(\mathrm{X}_{5}\right)$.

Data dalam penelitian dianalisis menggunakan statistika inferensial, yaitu Analisis Regresi Berganda. Pada Analisis Regresi Linier Berganda ada empat asumsi yang harus dipenuhi, yaitu residual menyebar normal dan saling bebas, tidak terjadi multikolinieritas antar variabel bebas, memiliki ragam yang homogen dan error tidak terikat terhadap peubah bebas (Mattjik dan Sumertajaya, 2008).

Hasil Analisis Regresi Linier akan diperoleh model matematis antara variabel bebas dan variabel terikat. Pada model dapat dijelaskan bagaimana besaran pengaruh dari variabel bebas terhadap variabel terikat berdasarkan satuannya masing-masing. Kebaikan model dapat dilihat dari nilai R2 yang diperoleh. Pengujian model dilakukan dengan menguji nilai $p$ dari hasil perhitungan nilai $F$ hitung dan $t$ hitung terhadap nilai $\alpha$ yang digunakan. Hasil pengujian dikatakan signifikan jika nilai $p$ lebih kecil dari nilai $\alpha$ yang telah ditentukan peneliti. 


\section{HASIL DAN PEMBAHASAN}

Data kriminalitas dalam penelitian ini merupakan data dari 15 kota/kabupaten di Provinsi Sumatera Selatan. Perkembangan jumlah kriminalitas di Provinsi Sumatera Selatan cukup berkurang dari 2017-2019. Namun meskipun demikian jumlah kriminalitas masih tinggi. Pada tahun 2019, jumlah kriminalitas di Sumatera Selatan tertinggi terjadi di Kota Palembang yang merupakan ibukota provinsi, dengan jumlah kasus kriminalitas sebanyak 4.703. Sedangkan jumlah kriminalitas paling sedikit terjadi di Kota Pagar Alam, yakni sebanyak 156 kasus kriminalitas yang dilaporkan. Angka ini memang cenderung menurun dari tahun 2017 dan 2018. Hal ini memang cukup baik, namun tetap saja masih tinggi dan harus terus diturunkan.

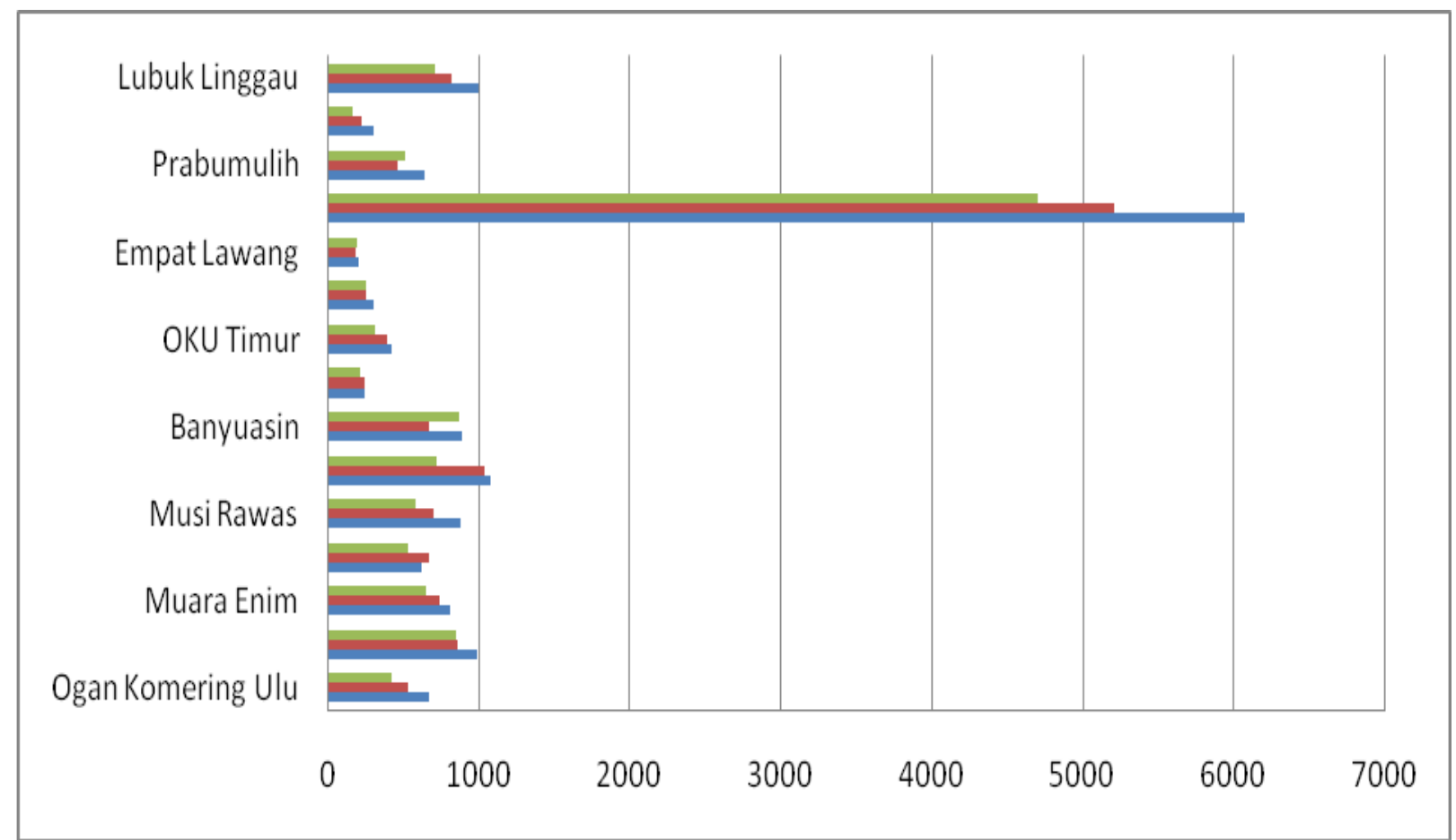

Sumber : Badan Pusat Statistik (BPS) Sumatera Selatan 2020

\section{Gambar Jumlah Kriminalitas di Kota/Kabupaten di Sumsel Tahun 2017-2019}

Sebelum melakukan Analisis Regresi Linier, dilakukan pengujian dengan analisis korelasi untuk melihat apakah ada hubungan antara variabel terikat dan variabel-variabel bebasnya. Hasil menggunakan metode korelasi pearson, diketahui bahwa variabel penduduk miskin, variabel tingkat pengangguran terbuka, variabel kepadatan penduduk, variabel IPM memiliki hubungan dengan variabel jumlah kriminalitas. Jika antar variabel memiliki hubungan (nilai korelasi $-1<r<1$ artinya variabel memiliki hubungan satu sama lain dan dapat dilanjutkan untuk melakukan Analisis Regresi Linier untuk mendapatkan model matematis pengaruh masingmasing variabel bebas terhadap variabel terikat. 
Tabel Nilai Korelasi Pearson Antar Variabel

\begin{tabular}{l|l|l|l|l|l|l}
\hline & JK & JPM & TPT & KP & IPM & PDRB \\
\hline \multirow{3}{*}{\begin{tabular}{l} 
JK $\begin{array}{l}\text { Pearson } \\
\text { Correlation }\end{array}$ \\
\cline { 2 - 7 }
\end{tabular}} & 1 &, $789^{* *}$ &, $785^{* *}$ &, $961^{* *}$ &, $699^{* *}$ &, 284 \\
\hline Sig. (2-tailed) & &, 000 &, 001 &, 000 &, 004 &, 304 \\
\hline
\end{tabular}

*. Correlation is significant at the 0.05 level (2-tailed).

Persentase nilai Korelasi Pearson yang diperoleh dari kelima variabel tersebut berturut-turut adalah 78,9\%, 78,5\%, 96,1\%, 69,9\% dan 28,4\%. Variabel Jumlah Penduduk Miskin, Tingkat Pengangguran Terbuka, Kepadatan Penduduk dan IPM memiliki hubungan yang kuat dengan Jumlah Kriminalitas. Sedangkan variabel PDRB dalam hal ini terlihat hubungan yang tidak terlalu kuat dengan jumlah kriminalitas, yakni hanya 28,4\%. Meskipun demikian, variabel PDRB tetap akan diikutsertakan dalam Analisis Regresi Linier karena variabel PDRB tetap memiliki hubungan dengan Jumlah Kriminalitas meskipun tidak terlalu kuat.

Hasil Analisis Regresi Linier diperoleh model matematis sebagai berikut :

$$
\overparen{I K}=233004+7,5 \mathrm{JPM}+20,6 \mathrm{TPT}+0,76 \mathrm{KP}-7,67 \mathrm{IPM}+24,85 \mathrm{PDRB}
$$

Hasil pemodelan matematis jumlah kriminalitas (JK) di Sumatera Selatan dapat dijelaskan bahwa variabel Jumlah Penduduk Miskin (JPM), variabel Tingkat Pengangguran Terbuka (TPT), variabel Kepadatan Penduduk (KP), dan variabel PDRB memberikan pengaruh positif terhadap Jumlah Kriminalitas(JK), artinya jika variabel-variabel tersebut bertambah nilai/jumlahnya per satuan maka akan meningkatkan jumlah kriminalitas di Sumatera Selatan. Sedangkan variabel Indeks Pembangunan Manusia (IPM) memberikan pengaruh negatif, artinya jika nilai IPM meningkat satu persen maka akan menurunkan jumlah kriminalitas di Sumatera Selatan. Pada pemodelan yang diperoleh terlihat masing-masing variabel bebas memiliki masing-masing koefisiennya. Artinya setiap kenaikan setiap variabel bebas akan menambah jumlah kriminalitas sebanyak nilai koefisien masing-masing yang telah diperoleh dari hasil Analisis Regresi Linier.

Pembahasan masing-masing dari koefisien variabel bebas ini tentu saja harus dikaitkan dengan teori-teori yang berlaku dan beberapa penelitian sebelumnya. Pada Analisis Regresi Linier pengujian model secara bersama-sama (simultan) dari semua variabel bebas yang digunakan dilakukan dengan melihat nilai $F$ hitung dan nilai $p$ yang diperoleh dibandingkan dengan a yang telah ditentukan. Hasil analisis memperoleh nilai $F$ hitung sebesar 12,383 dan nilai $p$ sebesar 0,000 , jika dibandingkan dengan nilai a 0,05 maka diartikan bahwa secara bersama-sama (simultan) variabel Jumlah Penduduk Miskin $\left(X_{1}\right)$, Tingkat Pengangguran Terbuka $\left(\mathrm{X}_{2}\right)$, Kepadatan Penduduk $\left(\mathrm{X}_{3}\right)$, Indeks Pembangunan Manusia $\left(\mathrm{X}_{4}\right)$, dan PDRB signifikan secara statistik memberikan pengaruh terhadap Jumlah Kriminalitas di Sumatera Selatan. 
Tabel Nilai Koefisien Regresi, t hitung dan FIF Variabel-Variabel Bebas Coefficients $^{\mathrm{a}}$

\begin{tabular}{|c|c|c|c|c|c|c|c|}
\hline \multirow{2}{*}{\multicolumn{2}{|c|}{ Model }} & \multicolumn{2}{|c|}{$\begin{array}{l}\text { Unstandardized } \\
\text { Coefficients }\end{array}$} & $\begin{array}{c}\text { Standardized } \\
\text { Coefficients }\end{array}$ & $\bar{T}$ & Sig. & $\begin{array}{c}\text { Collinearity } \\
\text { Statistics }\end{array}$ \\
\hline & & B & Std. Error & Beta & & & VIF \\
\hline \multirow{6}{*}{1} & (Constant) & 233,004 & 1954,710 & & ,119 & ,908 & \\
\hline & JPM & 7,467 & 1,600 & ,300 & 4,668 & ,001 & 2,545 \\
\hline & TPT & 20,590 & 84,740 & ,027 & 243 & 813 & 7,611 \\
\hline & $\mathrm{KP}$ & ,755 & ,097 & ,770 & 7,805 & ,000 & 5,987 \\
\hline & IPM & $-7,669$ & 31,093 &,- 026 &,- 247 & ,811 & 6,857 \\
\hline & PDRB & 24,854 & 64,989 & ,021 & ,382 & ,711 & 1,831 \\
\hline
\end{tabular}

a. Dependent Variable: Jumlah Kriminalitas

Sumber: Pengolahan Data Dengan SPSS 21

Nilai $R^{2}$ sebesar $98,5 \%$ berarti model yang diperoleh sudah sangat baik untuk digunakan sebagai gambaran dan untuk prediksi pengaruh variabel Jumlah Penduduk Miskin $\left(X_{1}\right)$, Tingkat Pengangguran Terbuka $\left(X_{2}\right)$, Kepadatan Penduduk $\left(X_{3}\right)$, Indeks Pembangunan Manusia $\left(X_{4}\right)$, dan PDRB terhadap Jumlah Kriminalitas di Sumatera Selatan. Kelima variabel bebas tersebut telah dapat menggambarkan pengaruh dari jumlah kriminalitas. Sedangkan 1,5\% lainnya dijelaskan oleh variabelvariabel bebas lainnya yang tidak dimasukan dalam analisis.

Berdasarkan nilai VIF yang diperoleh semua variabel bebas memiliki nilai VIF>10, hal ini berarti bahwa tidak ada hubungan antara variabel-variabel bebas yang digunakan satu sama lainnya. Jadi ketika nilai uji $\mathrm{F}$ menunjukkan bahwa variabel bebas berpengaruh terhadap jumlah kriminalitas dapat dipenuhi dengan tingginya nilai $R^{2}$ dan diikuti dengan mengamati asumsi-asumsi klasik Analisis Regresi yang harus terpenuhi, salah satunya non multikolinieritas yang dilihat dari nilai VIF yang diperoleh.

Tabel Ringkasan Model

\begin{tabular}{llllll}
\hline Model & $\mathrm{R}$ & $\mathrm{R}$ & $\begin{array}{l}\text { Adjusted } \\
\text { Square }\end{array}$ & $\begin{array}{r}\mathrm{R} \text { Std. Error of Durbin- } \\
\text { the Estimate }\end{array}$ & $\begin{array}{l}\text { Watson } \\
\text { Square }\end{array}$ \\
\hline 1 &, $993^{\mathrm{a}}$ &, 985 &, 977 & 167,69821 & 1,332 \\
\hline
\end{tabular}

Sumber: Pengolahan Data Dengan SPSS 21

Tabel Tabel ANOVA

\begin{tabular}{|c|c|c|c|c|c|c|}
\hline \multirow{3}{*}{1} & Model & $\begin{array}{l}\text { Sum of } \\
\text { Squares }\end{array}$ & $d f$ & Mean Square & $F$ & Sig. \\
\hline & Regression & 17067903,541 & 5 & 3413580,708 & 121,382 &, $000^{\mathrm{b}}$ \\
\hline & $\begin{array}{l}\text { Residual } \\
\text { Total }\end{array}$ & $\begin{array}{l}253104,192 \\
17321007,733\end{array}$ & $\begin{array}{l}9 \\
14\end{array}$ & 28122,688 & & \\
\hline
\end{tabular}

Sumber: Pengolahan Data Dengan SPSS 21 
Jika ditinjau dari nilai $t$ hitung yang diketahui bahwa variabel TPT, IPM dan PDRB tidak signifikan berpengaruh terhadap jumlah kriminalitas. Hal ini bersesuaian dengan diperolehnya nilai dugaan dari variabel PDRB yang tidak bersesuaian dengan teori yang ada. Seharusnya PDRB memberikan pengaruh yang positif terhadap jumlah kriminalitas, bukan sebaliknya.

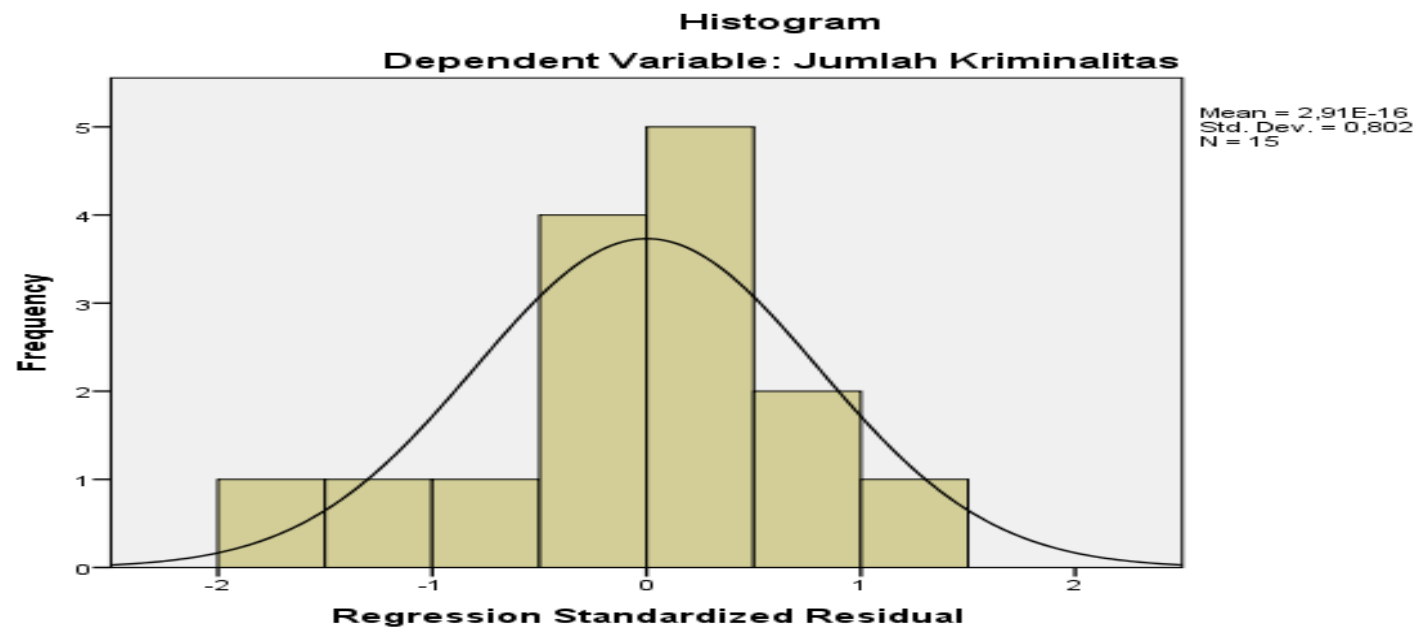

Gambar Histogram Kenormalan Data

\section{Sumber : Pengolahan Data Dengan SPSS 21}

Asumsi lainnya adalah kenormalan data, dari histogram dapat terlihat bahwa data yang digunakan menyebar normal.

Jumlah Penduduk Miskin (JPM) berpengaruh positif terhadap jumlah kriminalitas di Sumatera Selatan. Berdasarkan model regresi yang diperoleh artinya setiap penambahan seribu jumlah penduduk miskin maka akan menambah kriminalitas sebanyak 7 tindak kriminal.

Menurut Nasrullah 2015 dalam Dulkiah dan Nurjanah 2018, kemiskinan adalah kondisi kehilangan sumber-sumber pemenuhan kebutuhan dasar berupa pangan, sandang, papan, pendidikan dan kesehatan serta hidup serba kekurangan.

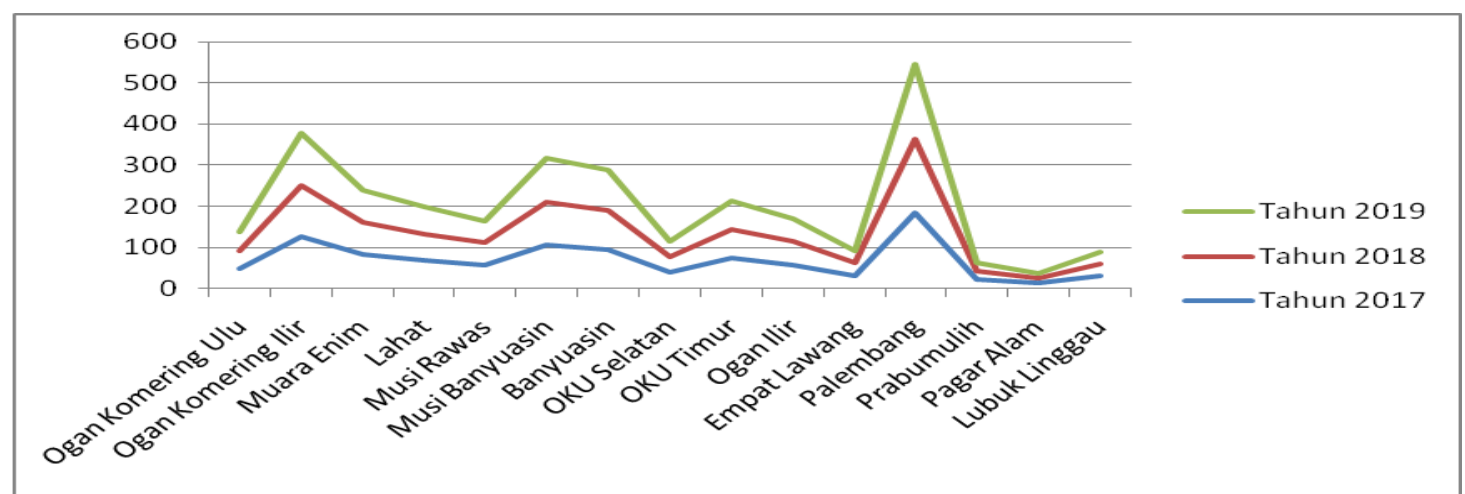

\section{Gambar Jumlah Penduduk Miskin Di Sumatera Selatan}

\section{Sumber : Data BPS Sumatera Selatan Dalam Angka 2020}

Jumlah penduduk miskin di Sumatera Selatan Tahun 2017 sampai Tahun 2019 terus mengalami peningkatan di 15 kota/kabupaten di Sumatera Selatan. Hal ini 
tentu saja semakin membawa dampak buruk dalam berbagai aspek, salah satunya diduga pertambahan penduduk miskin adalah salah satu faktor yang mempengaruhi jumlah kriminalitas. Padahal tidak selalu kondisi kemiskinan menyebabkan seseorang melakukan tindak kriminal.

Menurut Sukirno 2006 dalam Nadilla 2018, pengangguran terbuka tercipta akibat adanya pertambahan tenaga kependidikan kerja, namun lowongan pekerjaan yang lebih rendah. Pada model regresi yang diperoleh setiap penambahan nilai Tingkat Pengangguran Terbuka (TPT) maka akan menambah jumlah kriminalitas sebanyak 20 tindak kriminal. Angka ini cukup besar dan menjadi permasalahan besar bagi pihak terkait. Setiap tahunnya jumlah pengangguran terbuka terus meningkat dan masih sangat sulit untuk dikendalikan. Penambahan lapangan pekerjaan yang menjadi kunci utamanya. Saat ini, perintah sangat mendorong fenomena menjamurnya pelaku UMKM. Kegiatan usaha-usaha mandiri seperti UMKM sedikit menjadi solusi awal untuk mengurangi pengangguran.

Pengangguran dapat menimbulkan ketidakstabilan sosial dan politik, kegiatan ekonomi yang menurun. Permasalahan pengangguran ini sangat berkaitan dengan faktor kemiskinan. Jika perlahan permasalahan pengangguran dapat diturunkan, maka akan berpengaruh pula terhadap jumlah penduduk miskin dan serta akan mengurangi jumlah kriminalitas pula.

Variabel Kepadatan Penduduk juga memberikan pengaruh positif terhadap jumlah kriminalitas di Sumatera Selatan. Setiap penambahan satu satuan kepadatan penduduk akan menambah tindak kriminal sebesar 0,76 persen. Hal ini memang tidak terlihat begitu besar penambahan dari pengaruh variabel kepadatan penduduk. Namun jika dikaitkan dengan teori kepadatan penduduk, artinya setiap penambahan jumlah penduduk per $1 \mathrm{~km}^{2}$ maka akan meningkatkan jumlah tindak kriminalitas. Hal ini juga sejalan dengan teori yang ada bahwa kepadatan penduduk dapat mempengaruhi kualitas hidup penduduknya. Pada daerah yang memiliki kepadatan penduduk yang tinggi, maka upaya peningkatan kualitas penduduk akan dirasakan lebih sulit.

Kepadatan penduduk tidak selamanya berpengaruh positif terhadap tindak kriminal, terkadang pada kondisi tertentu kepadatan penduduk dapat berpengaruh negatif terhadap kriminalitas karena ada faktor lainnya yang mempengaruhi jumlah kepadatan penduduk (Audey dan Ariusni 2019). Hal ini bermakna bahwa dengan kepadatan penduduk membuat keamanan meningkat jika kerukunan antar penduduk baik dan tingkat pengamanan yang baik pula.

Begitu juga halnya dengan variabel PDRB, turut memberikan pengaruh positif terhadap Jumlah Kriminalitas di Sumatera Selatan. Berdasarkan model matematis yang diperoleh dapat dikatakan bahwa setiap kenaikan PDRB maka akan menambah jumlah kriminalitas di Sumatera Selatan sebanyak 24 kejadian. Hal ini merupakan nilai yang sangat besar, namun secara uji parsial dengan nilai uji $t$ terlihat bahwa variabel PDRB ini tidak signifikan berpengaruh terhadap jumlah kriminalitas.

Selanjutnya, variabel IPM memberikan pengaruh negatif terhadap jumlah kriminalitas. Setiap kenaikan nilai IPM sebesar satu persen maka akan mengurangi jumlah kriminalitas sebanyak 7 tindak kriminal. Hal ini tentu saja sejalan dengan teori yang telah berkembang saat ini. United Nation Development Programme (UNDP) menjelaskan bahwa pembangunan manusia merupakan proses dalam memperluas pilihan-pilihan bagi penduduk. Semakin cepat pembangunan manusia maka pertumbuhan penduduk mencapai peningkatan produkvitasnya. 
IPM digunakan untuk mengukur seberapa besar dampak yang ditimbulkan dari upaya untuk meningkatkan kemampuan modal dasar manusia. Ukuran pembangunan manusia dihitung dari angka pendidikan, kesehatan dan daya beli masyarakat. Semakin tinggi angka-angka tersebut dapat diartikan bahwa tujuan dari pembangunan telah tercapai. Perhitungan nilai IPM di titik beratkan pada perhitungan nilai indeks Harapan Hidup, Indeks Pendidikan dan Indeks Standar Hidup (BPS, 2019).

Upaya peningkatan nilai IPM merupakan suatu upaya besar yang dapat dilakukan untuk mengurangi tindak kriminal. Meningkatnya IPM menunjukkan bahwa kualitas sumber daya manusia juga terus meningkat. Kualitas sumber daya manusia dapat dilihat dari diperolehnya pekerjaan yang baik sehingga mendapatkan pendapatan yang tinggi, kemudian akan berpengaruh terhadap kesejahteraan hidup dan berkurangnya tindak kriminal.

Hal ini sejalan dengan penelitian yang dilakukan oleh Audey dan Ariusni 2019, bahwa IPM berpengaruh signifikan dan negatif terhadap kriminalitas di Indonesia, peningkatan IPM memberi dampak yang berarti terhadap kriminalitas di Indonesia. Koranti dan Widio, 2014, dalam penelitiannya tentang perkembangan kriminalitas di Jakarta berdasarkan aspek ekonomi-demografi menyebutkan terdapat langkah yang dapat diambil oleh pemerintah yaitu meningkatkan ketegasan dalam menghukum para pelaku kriminal, meningkatkan upah pekerjaan, meningkatkan tingkat pendidikan masyarakat dan perlu langkah untuk menciptakan rasa aman di lingkungan masyarakat.

\section{E. KESIMPULAN DAN SARAN}

1) Kesimpulan

Berdasarkan hasil analisis, dapat disimpulkan bahwa variabel Jumlah Penduduk Miskin, variabel Tingkat Pengangguran Terbuka, variabel Kepadatan Penduduk, variabel PDRB dan IPM signifikan berpengaruh terhadap jumlah kriminalitas di Sumatera Selatan. Variabel Jumlah Penduduk Miskin, variabel Tingkat Pengangguran Terbuka, variabel Kepadatan Penduduk, dan variabel PDRB memberikan pengaruh positif terhadap Jumlah Kriminalitas di Sumatera Selatan, artinya jika variabel-variabel tersebut bertambah nilai/jumlahnya setiap satuan maka akan meningkatkan jumlah kriminalitas di Sumatera Selatan. Dalam hal ini, dapat diartikan bahwa untuk mengurangi tindak kriminalitas di Sumatera Selatan yaitu dengan menurunkan jumlah penduduk miskin, menurunkan angka tingkat pengangguran terbuka, menurunkan jumlah pengangguran. Sedangkan variabel Indeks Pembangunan Manusia memberikan pengaruh negatif, hal ini berarti setiap kenaikan nilai IPM satu persen maka jumlah kriminalitas di Sumatera Selatan akan dapat menurun.

2) Saran

Peneliti menyarankan untuk perlunya dilakukan langkah-langkah yang dapat digunakan untuk menurunkan jumlah kriminalitas yaitu dengan menurunkan jumlah penduduk miskin dan pengangguran dengan menambah jumlah lapangan pekerjaan bagi masyarakat. Menaikkan nilai PDRB dan IPM sehingga kualitas sumber daya manusia meningkat dan berpengaruh nyata terhadap kesejahteraan dan perbaikan perekonomian masyarakat. 


\section{DAFTAR PUSTAKA}

Audey, R.P., Ariusni (2019). Pengaruh Kualitas Sumber Daya Manusia Terhadap Tingkat Kriminalitas Di Indonesia. Jurnal Ekonika : Jurnal Kajian Ekonomi Dan Pembangunan, 1 (2).

BPS (Badan Pusat Statistik). (2019). Sumatera Selatan Dalam Angka 2019. Palembang:BPS

\section{Palembang:BPS} (2020). Sumatera Selatan Dalam Angka 2020.

Dulkiah, M., Nurjanah. (2018). Pengaruh Kemiskinan Terhadap Tindak Kriminalitas Di Kota Bandung. Jurnal JISPO, 8(2).

Hardianto, F.N. (2019). Analisis Faktor-Faktor Yang Mempengaruhi Tingkat Kriminalitas Di Indonesia Dari Pendekatan Ekonomi. Jurnal Bina Majalah IImiah Fakultas Ekonomi Unpar, 13(2).

Koranti, K., Widio, P. (2014). Perkembangan Kriminalitas Di Wilayah DKI Jakarta dan Sekitarnya Berdasarkan Aspek Ekonomi-Demografi. UG Jurnal, 8 (5).

Lumenta, C.Y., John, S.K., Djoni, H., (2011). Analisis Jalur Faktor-Faktor Penyebab Kriminalitas Di Kota Manado. Jurnal IImiah Sains, 12 (2).

Mattjik, A.A., Sumertajaya, I.M (2008). Perancangan Percobaan dengan Aplikasi SAS dan Minitab. Institut Pertanian Bogor :Institut Pertanian Bogor Press.

Mardiyansyah, A.A., Ni, M.S (2020). Ketimpangan Ekonomi, Kemiskinan Dan Akses Informasi : Bagaimana Pengaruhnya Terhadap Kriminalitas Di Indonesia?. Jurnal Ekonika : Jurnal Ekonomi Universitas Kadiri, 5 (1).

Nadilla, U., Farlian, T. (2014). Pengaruh PDRB Perkapita, Pendidikan, Pengangguran, Dan Jumlah Polisi Terhadap Angka Kriminalitas Di Provinsi Aceh. Jurnal IImiah Mahasiswa Ekonomi Pembangunan Fakultas Ekonomi dan Bisnis Unsyiah, 3 (1).

Santoso, T., Zulfa, E.A., (2016). Kriminologi. Jakarta : RajaGrafindo Persada.

Sharp, A.M., et al (1996). Economics of Social Sigues, Twelf Edition. USA

Sukirno, S. (2018). Macroekonomi Modern. Edisi Tiga. Jakarta: Rajawali Pres.

Wirawan. (2015). Manajemen Sumber Daya Indonesia : Teori, Psikologi, Hukum keternagakerjaan, aplikasi dan penelitian : aplikasi dalam organisasi bisnis, pemerintah dan pendidikan. Jakarta: PT RajaGrafindo Persada. 